\title{
Stomperud i Bagdad
}

Cecilie Hellestveit ${ }^{\star}$, PhD, Seniorforsker, International Law and Policy Institute

Artikkelen foretar en analyse av Norges militære bidrag i Irak fra 2015 med utgangspunkt i folkerettens regler for militære utenlandsoppdrag. Artikkelen argumenterer for at de folkerettslige rammene for det norske militære bidraget i Irak på et par vesentlige punkter skiller seg fra andre nyere norske militære utenlandsoperasjoner. Den peker på tre utfordringer som det norske militære engasjementet i Irak derfor medfører: notoriteten til det militære oppdraget innad og utad, rettssikkerheten til norske soldater, og effektiviteten til soldater $\mathrm{i}$ en prekær rettslig situasjon.

Stikkord: folkerett • maktbruk • Irak • Syria • IS • norske militære utlandsoperasjoner

The article analyses the Norwegian military contribution to Iraq initiated in 2015 from the perspective of international law regulating military operations on foreign soil. It argues that this military operation is distinguished from other Norwegian military expeditions in recent decades. The article draws attention to three challenges that consequently arise: a low level of clarity concerning the nature and scope of the assignment, lack of legal guarantees calibrated to the tasks of the soldiers and finally poor efficiency resulting from a precarious legal situation.

\section{Innledning}

Den norske regjeringen besluttet i oktober 2014 å sende 120 norske soldater til Irak for å «bidra til å trene opp irakiske sikkerhetsstyrker» (Solberg 2014). Fra april 2015 er en kontingent stasjonert i den kurdiske provinshovedstaden Irbil, formelt underlagt sikkerhetsstyrkene til den autonome kurdiske regionen i Nord-Irak (KRG), mens en annen er stasjonert i hovedstaden Bagdad. Militærpersonalet skal støtte irakiske sentralmyndigheter og kurdiske regionale myndigheter i kampen for å gjenerobre territorium fra organisasjonen Islamsk Stat (IS), som i 2015 kontrollerte ca. 1/3 av Irak (Institute for the Study of War 2015). ${ }^{1}$ Norsk deltakelse er en del av en løst ledet amerikansk koalisjon for å «degradere og til slutt knuse» IS gjennom å redusere IS geografiske og politiske rom, menneskelige og økonomiske ressurser (Det Hvite Hus 2014, 2014a).

^Korrespondanse: Cecilie Hellestveit, International Law and Policy Institute. Email: ch@ilpi.org ${ }^{1}$ IS omtales også som ISIL, en forkortelse for Islamsk Stat i Irak og Levanten, eller ISIS, som står for Islamsk Stat $i$ Irak og al-Sham, som er den arabiske benevnelsen for Stor-Syria. 
Denne artikkelen analyserer det norske militære nærværet i Irak fra 2015 i lys av folkerettens regler for maktbruk. Den presenterer først folkerettens hovedregler for militære operasjoner på fremmed jord, og plasserer deretter det norske nærværet i Irak fra 2015 i et folkerettslig lys. Artikkelen argumenterer for at nærværet i Irak representerer et brudd med tradisjonen for norske militære operasjoner på fremmed jord etter år 2000, og peker på tre utfordringer som nærværet til norske soldater i Bagdad derfor reiser. Det er uklarhet om hva som er norske soldaters oppdrag. Rettssikkerheten til norske soldater er ikke kalibrert for de oppgavene soldatene faktisk har. Og norske soldater i en prekær rettslig situasjon kan i begrenset grad utføre sine oppgaver så effektivt som forutsatt.

\section{Follkerettens regler for millitare operasjoner i utlandet}

En grunnregel i forholdet mellom verdens suverene stater er at en stats bruk av militærmakt i internasjonale forhold er forbudt, med mindre det foreligger et unntak som gir folkerettslig hjemmel, kjent som maktforbudet. FN-paktens artikkel 2(4) fra 1945 er en «hjørnesten i FN-pakten» som konsoliderte maktforbudet ved å forby trusler om eller bruk av makt i mellomstatlige forhold (ICJ 2005: 148). Maktforbudet anses også å være folkerettslig sedvane (ICJ 1986: 175-190; 2004: 87). Militær maktbruk som foregår på annen stats territorium krenker suverenitetsprinsippet, altså det formelle likhetsprinsippet mellom stater som i et klassisk utsagn har blitt uttrykt som «a dwarf is as much a man as a giant» (Vattel 1758:XVIII). Maktforbudet slår fast at uavhengig av størrelse, rikdom eller indre forhold $i$ en annen stat vil en stats maktbruk mot en annen stat eller på en annen stats territorium være folkerettsstridig dersom særlig hjemmel mangler. Dette gjelder også maktbruk som retter seg mot ikke-statlige aktører på annen stats territorium (Simma 2012: 216). Maktforbudet har to unntak som like fullt gjør militær maktbruk i utlandet lovlig.

\section{Kapittel VII-mandat}

Det første unntaket fra maktforbudet er militære operasjoner autorisert av FNs Sikkerhetsråd under FN-paktens kapittel VII som svar på en trussel mot internasjonal fred og sikkerhet, kjent som kapittel VII-mandat. FNs Sikkerhetsråd kan autorisere militær maktbruk under kapittel VII dersom det foreligger en trussel mot fred, et brudd på freden eller en aggresjonshandling (FN-pakten, artikkel 39). Blant annet kan Sikkerhetsrådet autorisere militære operasjoner mot en suveren stats myndigheter for å gjenopprette internasjonal fred og sikkerhet (FN-pakten artikkel 39; 42). Kapittel VII-mandat i snever forstand er hjemmel til å bryte maktforbudet gjennom militære operasjoner i den hensikt å håndheve annen folkerett.

En resolusjon kan også klargjøre lovligheten til en militæroperasjon selv om formen er annerledes (ICJ 1971: 114). Den Saudi-ledede operasjonen i Jemen i 2015 var basert på invitasjon fra Jemens myndigheter (Qatar 2015). Jemens president hadde mistet kontroll over hovedstaden og statsbærende institusjoner, men Sikkerhetsrådet bekreftet at han likefullt bevarte kompetanse til slik invitasjon (SRR 2216, 2015). Resolusjoner som bekrefter lovligheten av maktbruk endrer 
ikke hjemmelen, altså er operasjonen i Jemen basert på invitasjon og ikke mandat fra Sikkerhetsrådet.

En beslektet klargjøring av lovlighet finnes i Sikkerhetsrådets oppfordring fra november 2015 om adgang til å benytte «alle virkemidler» mot grupper i IS-kontrollerte områder i Syria og Irak for å hindre terrorisme (SRR 2249, 2015). Her er verken eksplisitte eller implisitte henvisninger til kapittel VII. Resolusjonen stadfester indirekte staters individuelle eller kollektive selvforsvarsrett mot IS og andre terror-grupper på syrisk og irakisk territorium. Det er ingen autorisasjon av maktbruk på syrisk og irakisk territorium av Sikkerhetsrådet mot nasjonale myndigheters vilje under kapittel VII, selv om effekten i visse begrensede henseender er lik. Den klargjør blant annet lovligheten av USAs luftmaktkampanje i Syria i 2014. Kampanjen startet kun timer før et møte i Sikkerhetsrådet og fikk dermed en implisitt aksept av Sikkerhetsrådet. Sikkerhetsrådsresolusjon 2249 bekrefter i realiteten denne aksepten. Resolusjonen innebærer at Sikkerhetsrådet gir samtykke til maktbruk som foregår på IS-kontrollert territorium. I praksis har Sikkerhetsrådet gjennom Sikkerhetsrådsresolusjon 2249 klargjort at militære (luft)operasjoner fra blant annet fire av Sikkerhetsrådets fem medlemmer på syrisk og irakisk territorium innenfor disse rammene ikke kan fremstilles som folkerettsstridig (Tyskland 2015).

Kapittel VII-mandat setter klare folkerettslige skranker for maktbruken. Operasjonene må utføres innenfor rammene av mandatet. Et kapittel VII-mandat autoriserer bruk av alle nødvendige midler for å oppnå formålet, men heller ikke mer. Maktbruken må dertil være proporsjonal med det identifiserte formålet (Gardam 2004; Dinstein 2011). Militære operasjoner for formål som ligger utenfor mandatet eller som er uproporsjonale med formålet representerer et brudd med maktforbudet.

Det følger også et knippe rettsvirkninger med kapittel VII-mandat. Sikkerhetsrådet setter til side statsmyndighetenes suverene rettigheter på det området mandatet gjelder. Et mandat pålegger alle FNs medlemsland å samarbeide eller i det minste ikke motarbeide en militæroperasjon (FN-pakten artikkel 25). Et mandat avskjærer også muligheten til å påberope seg selvforsvar mot operasjoner som skjer i medhold av mandatet. Dersom Sikkerhetsrådet bekrefter lovligheten av militær maktbruk, kan den ikke lenger karakteriseres som «folkerettsstridig». Dermed kan andre stater ikke påberope seg selvforsvar mot maktbruken. Her ligger en viktig effekt av Sikkerhetsrådsresolusjon 2249 for Syria. Lovligheten av angrepene i Syria har gjentatte ganger blitt utfordret av Assad-regimet (Syria 2015), og Bagdad (Irak 2015a). Når Sikkerhetsrådsresolusjon 2249 bekrefter lovligheten av disse angrepene kan verken Damaskus eller Bagdad hevde at operasjonene er aggresjonshandlinger som utløser deres rett til selvforsvar. Sikkerhetsrådet har slått fast at selvforsvar mot IS (og visse andre ikke-statlige grupper) i Syria og Irak ikke er folkerettsstridig. Sikkerhetsrådsresolusjon 2249 demper dermed visse farer for eskalering i og rundt Syria og Irak på bakgrunn av anklager om folkerettsstridig maktbruk, og påfølgende militære handlinger for å stanse slik folkerettsstridig maktbruk.

Kapittel VII-mandat er det klareste, synligste og mest forutsigbare av alle hjemmelsgrunnlag for militær maktbruk på fremmed jord. Det signaliserer at alle store makter er ombord. Et FN-mandat avskjærer muligheten til å hevde selvforsvar 
mot maktbruken, og pålegger alle FNs medlemsland å ikke motarbeide militæroperasjonen. Krav om FN-mandat som hjemmel for maktbruk er med andre ord noe ganske annet enn «FN-svermeri».

\section{Selvforsvar}

Det andre unntaket fra maktforbudet er adgang til militære operasjoner på fremmed jord for nasjonalt eller kollektivt selvforsvar. Reglen er kodifisert i FN-paktens artikkel 51, og gir rett til maktbruk i forsvar mot folkerettsstridig angrep. Selvforsvarsretten utløses ved et «væpnet angrep». Hovedbolken av stater og folkerettsjurister har tolket dette unntaket strengt (Kelsen 1950; Jessup 1968; Gardam 2004; David 2008; Gray 2008; Dinstein 2011). Selvforsvarsretten kan være individuell eller kollektiv. I sistnevnte tilfelle ber et land som har individuell selvforsvarsrett om hjelp fra andre stater (ICJ 1986: 105).

Maktbruk i selvforsvar utenfor suverent territorium vil ikke gi pålegg om samarbeid fra andre stater slik som et kapittel VII-mandat. Andre stater kan ta stilling for eller imot operasjonen, eller kan påberope seg nøytralitet. Dette endres dersom selvforsvarsretten bekreftes av Sikkerhetsrådet (FN-pakten artikkel 25; Heintschel von Heinegg 2007).

Begrensningen på operasjoner i selvforsvar er at de må være nødvendige (for forsvar) og proporsjonale (ICJ 1986: 94, 237; 1996: 41; 2003: 43,73-76; Trapp 2007: 141). Det vil si at operasjonenes skader må stå i forhold til de interessene som operasjonene hevdes å forsvare. Da Israel angrep Libanon etter innledende angrep fra Hizbollah mot israelsk territorium og et påfølgende bakholdsangrep i Libanon i 2006, var det generelt ansett at operasjonen var i tråd med Israels selvforsvarsrett (Israel 2006). Måten Israel svarte på, ble imidlertid av mange, som Frankrike, Russland og EU, kritisert for å være uproporsjonal og derfor i økende grad folkerettsstridig, fordi operasjonene gikk ut over det som var nødvendig og forholdsmessig for å hindre tilsvarende angrep i fremtiden (FNs Sikkerhetsråd 2006).

Et viktig trekk ved selvforsvarsreglene i artikkel 51 er at de ikke kommer til anvendelse på statsmaktens myndighetsutøvelse på suverent territorium. Irakiske myndigheter kan for eksempel ikke påberope seg selvforsvar mot IS i Irak. Her er det statsmaktens myndighetsutøvelse som er den folkerettslige knaggen. Folkeretten gir ikke på noe tidspunkt statsmakten «rett» til å krige mot egen befolkning basert på argumenter om selvforsvar. Tilsvarende gjelder denne typen (ad bellum) selvforsvarsrett heller ikke på okkupert territorium (ICJ 2004 Higgins). Hjemler og skranker for okkupasjonsmaktens maktbruk skiller seg både fra selvforsvar mot ytre fiender og fra reglene om suveren maktutøvelse. ${ }^{2}$

Situasjonen i og rundt Syria, og mangel på kapittel VII-mandat i tradisjonell forstand har ført til en rekke anførsler om selvforsvar for andre staters militære maktbruk på syrisk jord. Amerikanernes luftangrep mot syrisk territorium startet 22 .

\footnotetext{
${ }^{2}$ Reglene for okkupasjonsmakten finnes i Haag-reglementet 1907, Genèvekonvensjon IV, Tilleggsprotokoll I, samt annen sedvanerett.
} 
september 2014 (Obama 2014c). USA har anført hele fire ulike selvforsvarshjemler for sine operasjoner på syrisk jord.

Det første anførte selvforsvarsgrunnlaget er rettet mot Nusra Fronten, en syrisk gruppe assosiert med al-Qaida, og særlig deres Khorasan-brigade (USA 2014c; Obama 2014a). ${ }^{3}$ Disse operasjonene har hjemmel i USAs verdensomspennende konflikt mot al-Qaeda og assosierte styrker - en operasjon med mange krevende og kontroversielle folkerettslige problemstillinger (USA 2015; AUMF 2001: 2a; Obama 2015). ${ }^{4}$ USA har dernest anført kollektivt selvforsvar, altså operasjoner for å ivareta selvforsvarsretten til Syrias naboland. Irak, Jordan, Kuwait, Qatar, UAE og SaudiArabia har påberopt seg selvforsvar mot IS i Syria. USA assisterer disse statene med selvforsvar mot IS i Syria (Obama 2014b). Tilsynelatende er dette også hjemmelen for amerikanske angrep mot irakiske IS mål i Libya fra november 2015 (Blanchard 2015: 23).

To andre selvforsvarsgrunnlag som har blitt benyttet i Syria er mer tvilsomme. USA, Australia, Canada og Tyrkia har anført at operasjoner mot IS i Syria er utført basert på selvforsvar mot en ikke-statlig gruppe som representerer en direkte trussel mot dem selv, og som operer fra et territorium hvor statsmakten enten ikke evner eller viljer å ta affære med gruppen (USA 2014c; Canada 2015; Australia 2015; Tyrkia 2015). En slik «evne eller vilje»-doktrine gjør suverenitet betinget av statsmaktens innsats overfor ikke-statlige grupper på eget territorium (Schmitt 2002; USA 2011). Dette kan fremstå som en naturlig forlengelse av statsmaktens suverene maktutøvelse, som dermed kan gi motiver og press for å øke statsmakters innsats mot ikke-statlige grupper på eget territorium. Andre land, og særlig store naboland som for eksempel Russland vil imidlertid i praksis kunne «beslutte» om en stat i tilstrekkelig grad har innfridd dette vilkåret for suverenitet. En slik folkerettsregel ville dermed representere en betydelig utvanning av maktforbudet. Evne eller viljedoktrinen representerer ikke en etablert forståelse av selvforsvarsretten per i dag.

Et siste hjemmelsgrunnlag som USA har anført er forsvar av USAs allierte (trente) grupper på bakken i Syria (USAs permanente representant til FN 2014). Et slikt forsvarsargument må anses å ligge langt utenfor selvforsvarsretten slik den tolkes i dag, og må i så fall avledes fra «ikke-statlige gruppers selvforsvarsrett». En slik regel ville gi sterke stater folkerettslig ryggdekning for å operere militært mot styresmaktene i en annen stat såfremt man kan identifisere ikke-statlige grupper i staten som man kan «forsvare», med andre ord i praksis maktforbudets endelikt. Maktbruken på vegne av syriske grupper vil imidlertid tilsynelatende dekkes av Sikkerhetsrådsresolusjon 2249 etter november 2015.

Selvforsvarsretten er det mest uhåndgripelige av hjemmelsgrunnlagene for maktbruk. Kjernen består av en grunnleggende rett til selvopprettholdelse. Imidlertid vil de aller fleste militære operasjoner kunne presenteres som en versjon av selvforsvar. Derfor har folkeretten alltid søkt stramme og stringente kriterier for dette unntaket fra

\footnotetext{
${ }^{3}$ Khorasan er IS sin benevnelse for Sentral-Asia, inkludert Afghanistan.

${ }^{4}$ Dersom amerikanerne skulle vedta en egen «autorization for the use of military force» for kampen mot IS vil dette kun ha internrettslig betydning i USA, men ingen folkerettslige effekter.
} 
maktforbudet. Sett under ett har retten til selvforsvar i FN-paktens artikkel 51 imidlertid blitt tolket noe utvidende siden 2001. Situasjonen i Syria og Irak synes dertil å presse statenes praksis rundt selvforsvarsretten enda noen hakk lenger.

\section{Invitasjon}

En tredje folkerettslig hjemmel for militær maktbruk på fremmed jord består $\mathrm{i}$ invitasjon eller samtykke fra statlige myndigheter i et fremmed land (Deeks 2013). Formålet kan være å assistere vedkommende statsmakt med å opprettholde orden internt, etablere et effektivt statsapparat, forsvare territoriet eller å hindre territoriet fra å bli utnyttet av ikke-statlige aktører til voldsbruk som kan true nasjonal eller internasjonal sikkerhet. Dette hjemmelsgrunnlaget er ikke noe unntak fra maktforbudet i FN-pakten (Wien-konvensjonen 1969 artikkel 41; ILC 2001). Slike militæroperasjoner har bakgrunn i den inviterende statsmakts suverenitet, og strider dermed ikke mot maktforbudet.

I prinsippet kan statlige myndigheter invitere andre lands myndigheter eller ikke-statlige organisasjoner til å assistere dem med maktbruk på eget territorium. Assad-regimet, i kraft av å være Syrias statlige myndigheter, kan invitere andre statlige myndigheter som Iran og ikke-statlige aktører som libanesiske Hizbollah til å assistere syriske myndigheter med maktbruk på syrisk territorium. Også russiske soldater i Syria er invitert av Assad-regimet. Da Russland i september 2015 innledet en militær offensiv i Syria sørget imidlertid Russland for å styrke sin folkerettslige ryggdekning gjennom implisitt aksept av Sikkerhetsrådet etter mønster fra den amerikanske presidenten året før. På dette tidspunkt hadde Assad-regimet mistet så mye territoriell kontroll de foregående månedene at stater som Saudi Arabia stilte spørsmål ved om Assad-regimet fortsatt bevarte retten til invitasion (Saudi protest HRC 2015).

Dersom slik maktbruk strekker seg utenfor den inviterende stat og over på en annen suveren stats territorium, krever maktforbudet imidlertid ny hjemmel. Irakiske styrker eller andre staters væpnede styrker på invitasjon fra Irak kan ikke uten videre bruke militærmakt mot IS på syrisk side av grensen. Det krever et annet folkerettslig grunnlag. I fravær av et kapittel VII-mandat høsten 2014 ville det kunne være enten invitasjon fra syriske myndigheter eller selvforsvar i tråd med FN-paktens artikkel 51. Amerikansk bruk av den tyrkiske luftbasen Incirlik for støtte til kinetiske operasjoner mot IS i Irak og Syria er basert på samtykke fra Tyrkia i 2015. Det gir rett til operasjoner i Tyrkia. For operasjoner i Syria og Irak må USA imidlertid ha selvstendige hjemler. Sikkerhetsrådsresolusjon 2249 adresserer nettopp dette, og gir altså en slags «kappe av folkerettslig lovlighet» til ulike typer militære operasjoner i Syria og Irak.

Militære operasjoner basert på invitasjon bryter ikke med maktforbudet. Likefullt kan mangler ved hjemmelsgrunnlaget bringe operasjonen på kant med FN-pakten. Invitasjonen må for det første være klart uttrykt. Det kan ikke forutsettes at staten ville ha samtykket «dersom den hadde blitt spurt» (ILC 2001: 20.6). Andre stater kan også betvile samtykkets genuine karakter (Dosvald-Beck 1985). Dernest må invitasjon komme fra myndigheter som (fortsatt) disponerer rett til slik 
invitasjon. Om man har denne retten vil påvirke styrkeforholdet i en borgerkrigssituasjon enormt. Statlige myndigheter kan miste retten til invitasjon dersom de drives fra statsbærende institusjoner. Sikkerhetsrådet har anledning til å bekrefte slik evne til invitasjon, som i Jemen, eller det kan avskjære slik rett. Da Sikkerhetsrådet anerkjente opposisjons-strukturen i Libya som «legitime representanter for det libyske folk» i 2011, kunne libyske styresmakter ikke lenger invitere andre til hjelp. I Syria kom aldri slik Sikkerhetsråds-støtte. Dermed kunne Assad-regimet invitere iranske soldater, libanesiske Hizbollah-krigere samt afghanske, pakistanske og irakiske militser til å sloss for seg, mens støtte til den syriske opposisjonen vil være folkerettsstridig uten å gå via Damaskus eller Sikkerhetsrådet.

Ved invitasjon oppstår ikke spørsmålet om andre staters posisjoner til en gitt militær operasjon umiddelbart. Utgangspunktet er imidlertid at det ikke påligger noen plikt til samarbeid om operasjonens formål. Dersom sendestatens maktbruk skulle gå ut over samtykket, er maktbruken folkerettsstridig. Kan den karakteriseres som et væpnet angrep, utløser den sågar samtykkestatens rett til selvforsvar mot sendestaten under FN-paktens artikkel 51. Utover dette gjelder ikke noe spesifikt avgrenset formål for invitasjon, selv om en vesentlig skranke er at en stat ikke kan gi bort en rett den ikke har.

Formålet med invitasjon vil avhenge av hva de territorielle styresmaktene ønsker, eller avtalen mellom myndighetene og sendestaten. Slike avtaler har normalt form av forsvarsavtaler eller 'status of forces agreements' (SOFA). De har to hovedformål. De klarlegger formålet med det militære bidraget, og gir militært personell strafferettslig immunitet for sitt nærvær og for handlinger som faller inn under oppdraget. Det gir synlighet og klarhet, eller såkalt notoritet, utad. Og det gir sikkerhet for soldatene og forutsigbarhet innad.

Alle stater kan i praksis organisere militæroperasjoner hvor som helst i verden, såfremt territorielle statlige myndigheter har invitert eller samtykket til en maktbruk som de selv disponerer rett til. Slik militær maktbruk på fremmed territorium bryter ikke med maktforbudet, noe som medfører at parlamentarisk støtte på hjemmebane ofte ikke er påkrevd. Invitasjon er følgelig et hjemmelsgrunnlag som i visse henseender representerer en tvilsom undergraving av nasjonale og internasjonale skranker for å begrense og kontrollere internasjonale militære operasjoner. Derfor er det også en lite heldig utvikling at invitasjon som hjemmelsgrunnlag for stridigheter på fremmed jord ser ut til å øke i omfang.

\section{Regler for stridighetene}

Selv om en eller flere av disse tre hjemlene foreligger, kan folkerettsbrudd oppstå som følge av måten operasjonene gjennomføres på. To ulike forhold setter skranker hver for seg. Det spesifikke hjemmelsgrunnlaget for en operasjon (jus ad bellum) må være i orden og maktbruk foregå innenfor hjemmelens rammer. I tillegg kommer folkerettens alminnelige regler som gjelder for alle militære operasjoner (jus in bello). Om man har hjemmel for maktbruken er adskilt og uavhengig av spørsmålet om militæroperasjonen foregår i tråd med folkerettens regler for den type konflikt operasjonen er del av. Blant de sistnevnte finnes regler om beskyttelse av krigens ofre, 
regler for stridighetene og regler som forbyr visse typer våpen. At en operasjon foregår i tråd med folkeretten innebærer både at folkerettslig hjemmelsgrunnlag finnes og respekteres, og at alminnelige folkerettslige regler for maktbruk overholdes.

Det finnes fire ulike regelsett $\mathrm{i}$ folkeretten som setter alminnelige skranker for militære operasjoner: reglene for mellomstatlig konflikt, okkupasjon, ikkemellomstatlig konflikt, samt regler som gjelder for militære operasjoner som foregår under terskelen for væpnede konflikt. Den første situasjonen reguleres primært av humanitærretten, mens sistnevnte reguleres av begrensninger under menneskerettighetsregimet. Okkupasjon og ikke-internasjonale konflikter reguleres i utstrakt grad av både humanitærretten og menneskerettighetene, men på ulikt vis. På et par vesentlige punkter skiller disse regelsettene seg fra hverandre, og pålegger ulike rettigheter og plikter. Dermed kan maktbruk som er lovlig under ett regelverk være folkerettsbrudd under et annet. Bruk av ekspanderende kuler eller tåregass er for eksempel tillatt ved rettshåndhevelse, men dersom disse midlene benyttes under stridigheter vil det klassifiseres som krigsforbrytelser (Roma-statuttene 1998 artikkel 8.2.e). Personer som har ansvaret for krigsforbrytelser må enten straffeforfølges av egne myndigheter eller utleveres. ${ }^{5}$ Videre er det kun i mellomstatlige konflikter eller under okkupasjon at norske soldater kan få krigsfangestatus om de tas til fange hos fienden. I tillegg er grensedragningen mellom militære mål og sivile også klarere under disse to regelsettene enn i ikke-internasjonale konflikter.

De alminnelige reglene for militæroperasjoner kommer automatisk til anvendelse når operasjonen gjennomføres. En stat kan ikke selv bestemme hvilket folkerettslig regelverk som gjelder. Det er partskonstellasjonene i konflikten som avgjør hvilke regelsett som kommer til anvendelse til enhver tid. Ulike regler kan gjelde ulike partskonstellasjoner parallelt. Dermed er det norske soldaters tilknytning til en part $\mathrm{i}$ en væpnet konflikt, soldatenes funksjon i forhold til krigføringen, samt hvilken type konflikt det dreier seg om, som avgjør hvilke alminnelige folkerettslige regler og skranker som gjelder for en norsk militæroperasjon. Dette er forhold som vil gjelde automatisk, og selv et Sikkerhetsrådsmandat under kapittel VII vil ha ytterst begrensede effekter på disse reglene. Hvilke regler som anvendes kan også endres underveis i en pågående operasjon som følge av forhold som norske myndigheter ikke nødvendigvis har noen som helst innvirkning på. Man er kort sagt prisgitt krigens gang.

\section{Eksempel på invitasjon - norsk militaert naevaer i Irak}

Sommeren 2014 ble verdens øyne atter rettet mot Irak etter at IS erobret viktige strategiske områder i nord-vestre deler landet, erklærte et islamsk kalifat, og begikk massive internasjonale forbrytelser mot irakiske soldater og religiøse minoriteter på Ninevah-platået i nord-Irak. Særlig gjaldt dette den såkalt Camp Speicher-

\footnotetext{
${ }^{5}$ Prinsippet aut dedere, aut judicare er kodifisert for mellomstatlige konflikter i 1. Tilleggsprotokoll til Genèvekonvensjonene av 1949. Imidlertid gjelder dette prinsippet kun fullt ut for krigsforbrytelser i mellomstatlige konflikter.
} 
massakren 12. juni 2014, hvor det anslås at over 1500 avvæpnede irakiske sjiamuslimske kadetter og soldater ble henrettet av IS i løpet av en ettermiddag. Overgrep mot den kuridske jezidi-minoriteten fikk mye oppmerksomhet sensommeren 2014, med handlinger som ifølge flere internasjonale undersøkelseskommisjoner vil kunne kvalifisere som folkemord (FN 2014 a).

18. september 2014 annonserte norske myndigheter at Norge ville svare på oppfordringen fra Irak om å bidra militært til å bekjempe IS. I oktober ble det besluttet at Norge skulle sende militære styrker til taktisk militær rådgivning og opplæring i Irak. Oppdraget skal ifølge norske myndigheter «medvirke til å sette de irakiske styrkene bedre i stand til å møte trusselen fra ISIL» gjennom at norske soldater utdanner og trener irakisk militært personell i KRG (kurdisk Irak) og Bagdad (Solberg 2014). Norsk personell deltar ikke selv i militære operasjoner, men er altså en del av det militære støtteapparatet som har som formål å sette irakiske sikkerhetsstyrker i stand til å opptre mer effektivt militært.

\section{Folkerettslig hjemmel for oppdraget i Irak}

Det foreligger ikke noe kapittel VII-mandat fra Sikkerhetsrådet som hjemler norsk militært nærvær i Irak. Etter at IS erobret deler av fire irakiske provinser og erklærte en islamsk stat på irakisk og syrisk territorium i juni, fastslo Sikkerhetsrådet i august 2014 at IS var å anse som en trussel mot Syria, Irak, Midtøsten og mot internasjonal fred og sikkerhet (SRR 2170, 2014). Imidlertid foreligger ingen autorisasjon til maktbruk under kapittel VII i forlengelsen av dette. At «FNs Sikkerhetsråd enstemmig har fordømt deres fremferd» (Solberg 2014) har ikke betydning i denne sammenheng. FNs Sikkerhetsråd fattet en resolusjon 24. september 2014 under kapittel VII som pålegger stater å bekjempe fremmedkrigere, men uten å autorisere maktbruk mot IS (SRR 2178, 2014). Operasjon Inherent Resolve er en løst organisert amerikansk operasjon uten FN-mandat (USA 2014, USA 2014b, USA 2014e). Den koordineres gjennom USAs sentralkommando (CENTCOM) i Tampa, Florida, men operasjonen er så løs at ulike land har egne operasjonsnavn (Operation Shader for Storbritannia, Operation Okra for Australia, Opération Chammal for Frankrike og Operation Impact for Canada).

En vesentlig del av operasjonene mot IS er basert på argumenter om selvforsvar (se over). Sikkerhetsrådet har konstatert at IS representerer en alvorlig trussel mot internasjonal sikkerhet (SRR 2170, 2014; 2178, 2014; 2199, 2015; 2249, 2015). FNs Sikkerhetsråd har dermed klargjort at stater kan påberope selvforsvarsrett selv om IS er en ikke-statlig aktør. Norge har imidlertid ikke anført selvforsvar for vårt nærvær i Irak. Kollektivt selvforsvar er avledet av selvforsvarsretten til land som er under angrep og som ber om assistanse (ICJ 1986: 195; Arimatsu og Schmitt 2014: 23). Norge hjelper Irak mot (primært) irakere $i$ Irak. Norge kan ikke hevde å hjelpe Irak til selvforsvar $i$ Irak ettersom det ikke finnes noen selvforsvarsregel for suveren maktutøvelse i folkeretten (ICJ 2004 Higgins). Irakiske myndigheter kan anføre selvforsvar for operasjoner på syrisk side av grensen, hvor Norge eventuelt kan bistå basert på kollektivt selvforsvar, men da altså på vegne av Bagdad. 
Det kan anføres at syriske og irakiske myndigheter har hjemmel til militære operasjoner på andre siden av grensen i kraft av Sikkerhetsrådsresolusjon 2249. Den klargjør at maktmidler kan benyttes for å hindre terrorangrep fra IS (og visse andre grupper) på det området som IS kontrollerer i Syria og Irak. Resolusjonen presiserer at operasjonene skal foregå «i overenstemmelse med folkeretten og FN-pakten» på områder kontrollert av IS i Irak og Syria for det formål å hindre og stanse terrorhandlinger begått av IS og andre (uspesifiserte) terrorgrupper, samt å tilintetgjøre det sikre tilholdsstedet organisasjonene har skaffet i Irak og Syria. Resolusjonen oppfordrer til koordinering, og er altså ikke en FN-fullmakt til å operere militært på syrisk eller irakisk territorium uten koordinering med styresmaktene i Bagdad og Damaskus. Irakiske myndigheter er fortsatt i førersetet for operasjonene i Irak. Når Norge er i Irak basert på invitasjon fra irakiske myndigheter, er det irakiske myndigheters suverene rett til slik invitasjon og ikke Sikkerhetsrådets aksept av slik maktbruk som er hjemmelsgrunnlaget.

Det norske militære nærværet i Irbil og Bagdad er altså hjemlet i invitasjon fra myndighetene i Irak. Norske myndigheter referer til at Irak «ved flere anledninger [har] bedt det internasjonale samfunnet om hjelp til å bekjempe ISIL», og at «Norge vil delta i Irak etter anmodning fra irakiske myndigheter, og dette utgjør et tilstrekkelig folkerettslig grunnlag for det norske bidraget»(Solberg 2014; Eriksen 2014).

Irak formaliserte sin anmodning om hjelp gjennom et brev til FNs Sikkerhetsråd datert 20. september 2014 (Irak 2014). Her ber irakiske myndigheter om at USA skal lede en internasjonal innsats for å slå til mot IS mål i Syria, men underlagt irakiske myndigheters eksplisitte samtykke. Formålet med hjelpen er uttrykt som å «bringe en slutt på den vedvarende trusselen mot Irak, beskytte Iraks borgere, og bevæpne irakiske styrker og sette dem i stand til å gjenerobre kontrollen over Iraks grenser». Ordlyden tilsier at dette omfatter mer enn kamp mot IS i snever forstand.

FNs Sikkerhetsråd bekreftet invitasjonen og dermed også irakiske myndigheters kompetanse til slik invitasjon (FN 2014). Årsaken til at Irak kunne trenge slik bekreftelse finnes i situasjonen i Irak sommeren 2014. Da Bagdads sikkerhetsapparat imploderte i nordlige provinser i møte med et avanserende IS sommeren 2014, inntok kurdiske styrker fra Irbil mange omstridte og strategisk viktige områder (Cordesman og Khazai 2014: 164). I september 2014, på det tidspunktet invitasjonen kom, kontrollerte Bagdad i praksis under $40 \%$ av irakisk territorium. ${ }^{6}$ FNs Sikkerhetsråd stadfestet at irakiske sentralmyndigheter like fullt bevarte sine suverene prerogativer, deriblant retten til invitasjon.

Dermed kan irakiske myndigheter også sette vilkår for slik maktbruk på ethvert tidspunkt, eller tilbakekalle samtykket når som helst (ICJ 2005: 47; ILC 2001: 20; Gill 2010: 299). Allerede i oktober 2014 uttrykte irakiske myndigheter at brevet sendt til FNs Sikkerhetsråd i september hadde begrensninger. «Vi ba om hjelp, men det gjaldt luftmakt» (Chan 2014). Uttalelsene ble tolket dithen at samtykkeanmodningen

\footnotetext{
${ }^{6}$ USA sørget samtidig for å skaffe et unntak i internlovgivningen i USA som muliggjorde direkte avtaler med regionale myndigheter, altså KRG, uten å gå veien via Bagdad (USA 2016)
} 
til FNs Sikkerhetsråd kun omfatter bruk av luftmakt under den amerikanske operasjonen Inherent Resolve (Arimatsu og Schmitt 2014: 8). Dette støttes av den etterfølgende praksisen irakiske myndigheter har hatt ovenfor naboland. Arabiske naboland i Gulfen var med på luftmaktoffensiven mot IS fra starten (Obama 2014c). Bagdad gav imidlertid beskjed i 2014 om at arabiske naboland ikke var ønsket på bakken i Irak (CBS 2014). I august 2015 underrettet irakiske myndigheter Sikkerhetsrådet om at også tyrkiske soldater måtte forlate Irak, et krav Irak fremmet gientatte ganger høsten 2015, med presiseringer til FNs Sikkerhetsråd om at tyrkiske militære verken får operere på bakken eller i luften over Irak (Irak 2015a og Irak 2015b). Irakiske myndigheter anser ikke bakkestyrker fra land i regionen å være omfattet av anmodningen til FNs Sikkerhetsråd. Utenfor dette står nabolandet Iran, som har en separat forsvarsavtale med Irak som gir iranske soldater rett til å operere på irakisk jord. Iran har også foretatt luftangrep mot IS i Irak fra desember 2014 uavhengig av den internasjonale koalisjonen. I november 2015 ble også et felles operativt koordineringssenter mellom Teheran og Damaskus etablert i Bagdad (AlArabiya 2015). Det nære militære samarbeidet mellom Irak og Iran gjør at Iran har et annet og bredere mandat for sitt nærvær i Irak enn land tilstede basert på anmodningen fra 2014. Andre arabiske Gulfland som Saudi Arabia er ikke invitert til å assistere Bagdad på bakken, mens nabolandet Tyrkia på sin side ikke er invitert til å assistere verken på bakken eller i luften.

Det er altså ikke innlysende at norske militære i Irak omfattes av invitasjonen overlevert FNs Sikkerhetsråd i september 2014. Anmodningen har et betydelig videre omfang enn kun krig mot IS, og omfatter ifølge irakiske myndigheter kun luftmakt, noe norske soldater i Irak ikke driver med. Hjemmelen for det norske militære nærværet i Bagdad er invitasjon, men hva denne invitasjonen er for, og hva den innebærer fremstår som høyst uklart. Forskjellen mellom norske militære og f.eks. australske, franske eller amerikanske i Irak, er at Norge ikke deltar i luftoperasjoner mot IS. Norske soldater er invitert til Irak for å delta i en luftoffensiv mot IS som de altså ikke deltar i.

\section{Skranker ved hjemmelsgrunnlaget}

Fra norsk side ble det «lagt til grunn at norske styrker ikke skal delta direkte i kamphandlinger» (Eriksen 2014). I likhet med den norske operasjonen i Irak i 20032005 ble det heller ikke satt noen særnorske begrensninger på den militære deltakelsen i 2014. Det er imidlertid stor forskjell mellom Norges Irak-operasjoner i 2003-2005 og i 2015, særlig fordi bidraget i 2003-2005 hadde en klarere operasjonell organisering og et mye tydeligere hjemmelsgrunnlag (se under). Når det folkerettslige hjemmelsgrunnlaget for militært nærvær i et fremmed land er svakt, uklart eller omstridt blir det desto viktigere med klare avtaler som regulerer oppdragets art og soldatenes situasion.

Invitasjon som hjemmelsgrunnlag reguleres vanligvis nærmere av en forsvarsavtale. USA har en strategisk ramme-avtale med Irak fra 2008 som fortsatt er i kraft (dette er en politisk, ikke en juridisk avtale). Iran har en forsvarsavtale fra 2011 med Irak. Det har ikke Norge. 
Alternativet er en mindre omfattende SOFA - status of forces agreement. Den kan være multilateral eller bilateral. NATO har en SOFA-avtale som normalt vil anvendes ved NATO-operasjoner. Denne gjelder ikke i Irak. I 2014 avslo irakiske myndigheter en felles SOFA-avtale for alle stater som deltok i kampen mot IS. Av historiske og politiske årsaker ville Irak fremforhandle slike avtaler bilateralt med hvert enkelt land, noe som gav Bagdad bedre kontroll med hvilke lands soldater som får adgang til Irak, samt hva de skal bedrive (New York Times 2011). Det foreligger heller ingen bilateral SOFA-avtale mellom norske og irakiske myndigheter som klargjør oppdragets art, regulerer norske myndigheters kontroll med norske soldater eller gir norske soldater immunitet fra represalier fra irakiske styresmakter. ${ }^{7}$

Et tredje alternativ som kan benyttes dersom det militære nærværet haster, vertslandet er ute av stand til å inngå avtaler eller bidraget er kort, er såkalt "A\&Tstatus». Dette er status som er analog til det som gis til administrativt og teknisk ansatte ved en diplomatisk post $\mathrm{i}$ henhold til Wien-konvensjonen om diplomatiske forbindelser. Gjennom utveksling av diplomatiske noter foreslo norske myndigheter slik status i brev til irakiske myndigheter tidlig i 2015, med presisering om at norske soldater skal kunne bære norsk militæruniform og våpen for personlig beskyttelse (Norge 2015). I svarbrevet fra Irak bekreftes det at norske soldater som «har diplomatisk pass eller tjenestepass» vil få status tilsvarende administrativt eller teknisk ansatte. Brevet sier imidlertid ingenting om uniform eller bevæpning (Irak 2015).

Andre land med soldater i Bagdad har også T\&A-status for sine bidrag i Irak. Australia har en avtale med innhold unndradd offentlighet etter anmodning fra irakiske myndigheter hvor soldater bl.a. gis T\&A-status. Amerikanere på bakken i Irak opererer primært under «CIA covert action authoritites», og kommer i en egen kategori (Cordesman og Khazai 2014: 257). I juni 2014 gav irakiske myndigheter T\&A-status til amerikanske soldater på linje med administrativt ansatte ved den amerikanske ambassaden i Bagdad - en ambassade med rundt 3000 ansatte (New York Times 2014). Norge synes å ha satset på samme modell. Forskjellen mellom norske militære og f.eks. australske, franske eller amerikanske, er at Norge er det eneste landet som har sendt soldater til Bagdad som ansatte ved en diplomatisk post som altså ikke eksisterer. Hvordan analogi til administrativt ansatte ved en diplomatisk post skal fungere all den tid Norge ikke har noen diplomatisk post i Irak er uklart.

T\&A-status gir etter Wien-konvensjonen immunitet til administrativt ansatte for opptreden «i tråd med sine oppdrag» (Wien-konvensjonen 1961 artikkel 37.2). Hva som er oppdraget til norske soldater er imidlertid ikke spesifisert. Forskjellen mellom diplomater og soldater på fremmed jord er ikke kun av overfladisk art, altså at den ene benytter diplomatiske virkemidler mens den andre benytter militære virkemidler. Diplomaters oppdrag er gitt, og spesifisert i internasjonale traktater. Begrepet «i tråd med oppdraget» under Wien-konvensjonen om diplomaters immunitet har derfor et klart definert innhold. Væpnede soldater på fremmed jord er i en helt annen

\footnotetext{
${ }^{7}$ Også andre enn Norge mangler SOFA-avtale i Irak, som f.eks. FN-operasjonen i Irak UNAMI (FN 2015b: 68).
} 
situasjon. Presumsjonen, altså antakelsen, er at soldater er på territoriet for å utøve makt. Det er per definisjon en atypisk oppgave for soldater å opptre på vegne av andre myndigheter enn sine egne. SOFAer skal nettopp erstatte en manglende felles forståelse av hva som er soldaters oppgaver - og begrensninger - på fremmed jord. T\&A-status gis normalt til militært personale $\mathrm{i}$ (høyere) administrative stillinger ikke soldater.

Den formelle irakiske anmodningen om støtte gjelder luftoperasjoner som norske soldater ikke deltar i. Status som administrativt diplomatisk personale tilknyttet en diplomatisk post som ikke eksisterer, gjør videre at det finnes få klare holdepunkter for hva «i tråd med oppdraget» innebærer. Norske soldaters status $\mathrm{i}$ Bagdad synes å være helt i det blå.

\section{Alminnelige regler}

Om hjemmelsgrunnlaget og oppdragets art er noe uklart, kommer imidlertid folkerettens alminnelige regler til anvendelse. Irakiske myndigheter har siden sommeren 2013 vært involvert i en borgerkrigslignende tilstand mot sunni-muslimske områder, altså de samme områdene hvor IS etterhvert har fått kontroll. Sikkerhetsrådet refererte til humanitærrett for Irak alt i 2012 (SRR 2061, 2012). Fra 2014 ble denne klassifiseringen også benyttet av ICRC og FNs menneskerettighetsråd (FN 2015: 2; 2015a). Betegnelsen 'ikke-internasjonal konflikt' er ikke begrenset til væpnede konflikter som foregår kun på ett territorium. Kampen mot IS strekker seg over to land, og involverer mer enn 60 nasjoner på en side og en ikke-statlig aktør på den andre, og har forgreininger til territorier i mange andre land. Det er ikke en intern konflikt, men den er per i dag ikke-internasjonal i folkerettslig forstand fordi man ikke kjemper mot en statlig aktør på IS sin side. Irak befinner seg verken i en situasjon med okkupasjon eller (per i dag) i en internasjonal væpnet konflikt. Her er det reglene for rettshåndhevelse og interne væpnede konflikter som gjelder.

Dette innebærer at det er humanitærrettens regler for ikke-internasjonale væpnede konflikter som kommer til anvendelse på norske soldater i den grad de har en militær funksjon linket til en av konfliktens parter. A trene soldater med det formål å øke deres militære kapasitet og effektivitet for å gjenerobre territorium fra en ikke-statlig organisasjon med territoriell kontroll må anses som en militær funksjon (ICRC 2005; ICRC 2009). Norske soldater vil dermed i folkerettslig forstand kunne være lovlige mål i visse situasjoner, selv om de ikke deltar direkte i kamphandlinger. Det er uklart hvilken effekt dette har på soldatenes status i Bagdad.

\section{Folkeretten og andre norske militare operasjoner på fremmed jord}

Etter årtusenskiftet har norske soldater vært involvert i flere militære operasjoner på fremmed jord som ikke har vært FN-operasjoner i betydningen fredsbevarende operasjoner under FN-kommando. Dette gjelder særlig militære operasjoner i Afghanistan (2001-2016), Irak (2003-2005) og Libya (2011). Til tross for stor ulikhet i kontekst og karakter, har alle tre operasjonene hatt det til felles at de folkerettslige rammene har vært klare. 
Det norske militære engasjementet i Afghanistan fra 2001 var innledningsvis utløst av kollektivt selvforsvar (Smith \& Thorp 2010). Sikkerhetsresolusjonene i kjølvannet av angrepene 11. september gav en folkerettslig ramme, og intervensjonen i Afghanistan ble ansett som lovlig basert på USAs rett til selvforsvar etter angrepet mot USA (SRR 1368, 2001; 1373, 2001). Operasjon Enduring Freedom (OEF) startet som en internasjonal konflikt mot Taliban, som på det tidspunktet var Afghanistans statlige myndigheter i betydningen Genèvekonvensjonenes felles artikkel 2 (mellomstatlig konflikt). Konflikten mot al-Qaeda var derimot en konflikt mot en ikke-statlig gruppe fra første øyeblikk.

ISAF ble opprettet av FNs Sikkerhetsråd under et kapittel VII-vedtak 20. desember 2001 (SRR 1386, 2001). Den FN-forhandlede Bonn-avtalen mellom utvalgte afghanske parter, etablerte overgangsmyndigheter og bad om opprettelse av en stabiliseringsstyrke for Kabul (Brahimi 2001). Konflikten i Afghanistan mot Taliban gikk deretter over $\mathrm{i}$ en ny fase, hvor Taliban ble en opprørsbevegelse som kjempet mot de nye styresmaktene. Formålet med ISAF var å støtte de nye afghanske myndighetene og sikre FN-personale, og resolusjonen ble fulgt av en avtale mellom den afghanske interimregjeringen og ISAF (Military Technical Agreement 2002). Stryken var eksplisitt $i k k e$ del av koalisjonsstyrken OEF som drev krig mot terrorisme i Afghanistan (Military Technical Agreement 2002: 4h). I 2003 overtok NATO ledelsen av operasjonen etter oppfordring fra FN og afghanske myndigheter, og ISAF fikk et landsomfattende kapittel VII-mandat fra FNs Sikkerhetsråd (SRR 1510, 2003). Utvidelsen av ISAF i Sikkerhetsrådsresolusjon 1510 hadde også en tilleggsforankring i en anmodning fra den afghanske regjeringen (Afghanistan 2003). Reglene som gjaldt for ISAF og assistanse til irakiske myndigheter var en kombinasjon av rettshåndhevelse og regler for stridighetene i ikke-internasjonale væpnede konflikter.

Våre militære operasjoner i Afghanistan hadde dermed hjemmel i kollektivt selvforsvar, kapittel VII-mandat og invitasjon fra den afghanske regjeringen - altså samtlige av alle tre mulige folkerettslige hjemmelsgrunnlag.

I 2003 sendte Norge et begrenset antall soldater til Irak i kjølvannet av invasjonen, etter at Sikkerhetsrådet autoriserte maktbruk under kapittel VII for å påskynde prosessen med å avslutte okkupasjonen av Irak (SRR 1511, 2003). Den forutgående invasjonen ble generelt ansett som et brudd med FN-pakten (se bl.a. Chilcotrapporten 2016). Sikkerhetsrådets klargjøring av lovlighet var derfor nødvendig for mange stater, deriblant Norge (Strøm Eriksen 2005; Bjørgo 2014: 30,51). Et begrenset norsk styrkebidrag deltok under operasjonen Combined foint Task Force 7 fra juni 2003. Året etter ble mandat til maktbruk fra Sikkerhetsrådet gjort betinget av suverene irakiske myndigheters ønsker, noe som i realiteten var en formalisering av samtykke, ettersom et rent kapittel VII-mandat nettopp har den karakteristikken at maktbruk ikke er underlagt den suverene viljen til territorialstatens myndigheter (SRR 1546, 2004). Det norske bidraget ble da videreført under Multinational Force-Iraq frem til desember 2005.

Selv om USA og Storbritannias Irak-invasjon var ansett som folkerettsstridig, var denne situasjonen endret på det tidspunkt da Norge sendte soldater til Irak. Norge assisterte okkupasjonsmakten, og deretter irakiske myndigheter, men altså hele 
veien med mandat under kapittel VII fra FNs Sikkerhetsråd. I likhet med Afghanistan var situasjonen rundt folkerettens regler for stridighetene komplisert, ettersom reglene for mellomstatlig konflikt, okkupasjonsretten og rettshåndhevelse kom til anvendelse på ulike deler av operasjonene for ikke-irakiske styrker. Utfordringen i 2003-2005 var et konglomerat av folkerettslige regimer. Norges valg om å ikke legge noen særlige begrensninger på styrkebidraget i 2003 lettet denne situasjonen noe. (Et helt annet problem var at utenlandske og irakiske aktører i liten grad respekterte visse folkerettslige regler.) I 2015 er imidlertid utfordringen snarere fravær av klare folkerettslige rammer (og fortsatt at irakiske aktører i liten grad respekterer visse av reglene). Norges tilsvarende tilnærming om å ikke legge begrensninger på styrkebidraget i 2014 fremstår derfor i et litt annet lys.

Libya-operasjonen Odyssey Dawn, som gikk over i NATO-ledede Unified Protector var basert på et kapittel VII-mandat fra FNs Sikkerhetsråd i 2011. Formålet var å beskytte sivile, håndheve FNs våpen-embargo og innføre flyforbudssone i landet (SRR 1973, 2011). Her deltok Norge med 6 jagerfly, som tilsammen fløy 615 sortier og slapp 567 bomber over libysk territorium frem til Norge trakk flyene ut i august 2011 (Regjeringen 2011). Operasjonen hadde klar folkerettslig hjemmel all den tid norske styrker deltok (Youssef 2013: 245-67; Gray 2013: 229-55; Pommier 2011: 171-93; Bartolini 2012: 242-79). Norge deltok her $i$ en internasjonal koalisjon av stater som sloss mot statlige myndigheter i Libya. I folkerettslig forstand forelå det en mellomstatlig konflikt som gjaldt de jure mellom oss (norske soldater og norske borgere for øvrig) og Gaddafis menn. Det var en klassisk internasjonal væpnet konflikt under Genèvekonvensjonenes fellesartikkel 2 hvor hele krigens folkerett kom til anvendelse.

Etter år 2000 har Norge hatt klare hjemler for sine militære utenlands operasjoner. FNs Sikkerhetsråd har forestått ulike typer hjemler til maktbruk under kapittel VII i samtlige tilfeller gjennomgått her. Hjemlene gav folkerettslig ryggdekning for Norge, klarhet rundt bidragets formål, og rammer rundt virksomheten for norske soldater. Sett i lys av dette representerer Norges militære bidrag i Irak fra 2015 noe nytt. Selv om den folkerettslige ryggdekningen for Norge ikke synes å være bestridt $\mathrm{i}$ betydningen at irakiske myndigheter anser norske soldater for å være fiendtlige soldater på linje med visse andre av koalisjonens land, fremstår invitasjonen likefullt som mangelfull. Den folkerettslige hjemmelen gir heller ikke klarhet rundt bidragets formål eller rammer rundt virksomheten til norske soldater i Irak i 2015 slik tilfellet har vært for operasjonene i Afghanistan, Irak 2003-2005 og i Libya.

\section{Tre utfordringer}

Invitasjon til assistanse er et hjemmelsgrunnlag hvor vi låner våre militære kapasiteter til en annen stat. En mottakerstat vil normalt ha andre motiver og interesser enn våre, og dertil være involvert $\mathrm{i}$ pågående maktkamper og potensielle militære konfrontasjoner som er Norge uvedkommende. Følgelig er det viktig med klare rammer for slikt utlån. Det noe ulne folkerettslige grunnlaget for Norges militære bidrag i Irak representerer derfor utfordringer på tre plan. 
Det første er notoritet. Det foreligger verken et FN-mandat eller en selvforsvarshjemmel for bidraget. Iraks anmodning til FNs Sikkerhetsråd om assistanse er bredt anlagt og med et uspesifisert formål som er betydelig videre enn kamp mot IS. Ingen forsvarsavtale eller SOFA er fremforhandlet som kan klargjøre oppdragets formål. Da oppstår et spørsmål om notoritet rundt formål og virkemiddel. Hvorfor har Norge sent soldater til Irak? To hensyn melder seg. Det ene retter seg mot norske forhold, og klarhet i hva norske soldater bedriver i land langt borte, med det som må karakteriseres som noe atypiske samarbeidspartnere, bl.a. med en rekke anklager om internasjonale forbrytelser de siste 5 årene (Audiencia Nacional 2010; HRW 2016). Sågar $\mathrm{FN}$ rapporterte om internasjonale forbrytelser begått av det irakiske sikkerhetsapparatet i 2015 (FN 2015: 50-69). Det andre retter seg mot andre stater. Det fremstår som uklart - og dermed overlatt til spekulasjon - hvorfor Norge har sendt soldater til Bagdad for å hjelpe en koalisjon som samarbeider nært militært med Teheran, Damaskus og Russland. Dette er en konflikt som amerikanerne beskriver på følgende måte: «Our interests align with none of our allies in this conflict» (Biddle i Ryan og Jaffe 2015). I denne sammenhengen fremstår for så vidt norsk nærvær i Irbil annerledes. Irbil er buffer for NATOs sørlige flanke. Kurdiske styresmakter i Irbil har en taktisk allianse med NATO-landet Tyrkia. KRG har også gjort en viss innsats for å bygge anstendige institusjoner de siste 13 år. Dertil fungerer Irbil som geografisk buffersone mellom IS-land eller borgerkriger mot sør og Tyrkia mot nord, og en rekke andre land som det er naturlig for Norge å sammenligne seg med er her (Sverige, Tyskland og Finland). Bagdad faller utenfor samtlige av disse kategoriene.

Kampen mot IS skjuler også en parallell intern konflikt med et eget liv i Irak. Sikkerhetsstyrkene som norske soldater trener i Irbil var i tilløp til væpnet konfrontasjon med sikkerhetsstyrkene vi trener i Bagdad senest i 2012 på bakgrunn av uenighet om grensene mellom KRG og arabisk Irak (Cordesman and Khazai 2014). Det har foreligget en latent løsrivningskonflikt mellom Bagdad og KRG i flere år, og stridigheter i 2012 mellom sikkerhetsstyrker fra Bagdad og Peshmergaer fra Irbil dreide seg om territoriell kontroll i omstridte områder sør for KRG. Denne stillingskrigen pågikk frem til urolighetene i Anbar i 2013 som i tur ledet til erobringen til IS i 2014. De omstridte områdene mellom Irbil og Bagdad sammenfaller nettopp med de oljerike områdene IS kontrollerer og som skal gjenerobres med norsk hjelp fra henholdsvis Irbil og Bagdad. Men hvordan områdene skal fordeles mellom Irbil og Bagdad er det altså langt fra enighet om. Ikke på noe tidspunkt etter sommeren 2014 har det vært et urealistisk scenario at soldater vi trener i Bagdad vil ønske å bruke sine ervervede militære ferdigheter til å sloss mot soldater vi trener i Irbil.

Hjemmelsgrunnlaget invitasjon stiller strengere krav til sendestatens myndigheter når det gjelder å klargjøre rammene for det militære oppdraget. Å låne ut norske soldater uten videre begrensninger eller spesifisering til aktører med en svært brokete fortid, og med interesser og motiver som i stor grad avviker fra norske, og hvor det dertil ligger i kortene at randsoneområder skal utsettes for «demografiske justeringer» før man når en politisk enighet, kan vanskelig sies å være i tråd med den etablerte tradisjonen for bruk av norske soldater i utlandet. 
Den andre utfordringen er norske soldaters rettssikkerhet. I mangel på andre avtaler ble norske soldater tilslutt utstyrt med status som administrativt og teknisk ansatte ved diplomatiske poster. Dette skjedde tilsynelatende etter kopi fra mer omfattende avtaler med USA, Frankrike og Australia. Disse landene driver med luftoperasjoner og omfattes dermed klart av Iraks anmodning til FNs Sikkerhetsråd. Norske soldater er invitert til Bagdad for å delta i en luftoperasjon de derimot ikke deltar i. Øvrige land som har soldater i Bagdad med A\&T-status har diplomatiske poster i hovedstaden som soldatene kan være tilknyttet som administrativt personell. Norske soldater er administrativt ansatte ved en diplomatisk post som derimot ikke eksisterer. Avtalen mellom Norge og Irak er basert på en diplomatisk overenskomst som er uspesifikk, og er en blåkopi av avtaler om diplomaters status. Diplomatisk immunitet innbefatter ikke noen form for rett til engasjement i militær aktivitet, altså det soldatene i praksis bedriver. Dermed er det en folkerettslig situasjon i disfavør av norske soldater. De deltar ikke i kamp. Det er imidlertid ikke ensbetydende med at de ikke har en militær funksjon som gjør at de kan oppfattes som lovlige mål. De bidrar i en ikke-internasjonal væpnet konflikt, hvor det altså etter humanitærretten ikke finnes kombattant-status, og hvor målutvelgelse foregår basert på funksjon. En integrert del av strukturen som øker militær kapasitet hos en part vil ikke ha sivil immunitet under folkeretten. At man er i landet med status som «diplomatisk ansatt» er saken uvedkommende. Det er uklart hva «i tråd med oppgaven» faktisk innebærer, noe som betyr at soldatene kun har en viss rettslig beskyttelse mot straffeforfølgelse eller represalier fra irakiske myndigheter. Soldatene kan være lovlige mål under folkeretten, men har ikke adekvat beskyttelse under det irakiske regimet. Norske soldaters rettsbeskyttelse er ikke kalibrert for de oppgavene de har eller den konteksten de opererer $\mathrm{i}$.

Det tredje er operasjonens effektivitet. Det er ikke gunstig å være prisgitt oppdragsgiver i en situasjon hvor man skal forsøke å lære en institusjon opp til å gjøre ting på annet vis. Norske soldater assisterer sikkerhetsstyrker som har vært involvert $\mathrm{i}$ mange og alvorlige folkerettsbrudd de senere år, bl.a. troverdige påstander om krigsforbrytelser og forbrytelser mot menneskeheten (FN 2015: 50-69; Amnesty 2014; HRW 2016). Irak er et av verdens mest korrupte land, og med store disiplinære utfordringer i sikkerhetsapparatet. Soldater uten adekvat rettsbeskyttelse eller lovlig opphold, vil ha svært lite å gå på i forhold til å påpeke kritikkverdige forhold overfor oppdragsgiver. Det innebærer at den norske kontingenten må antas å være mindre effektiv $i$ forhold til instruering eller opplæring av et haltende irakisk sikkerhetsapparat enn det som presumptivt er forutsetningen.

Et lite land som Norge vil alltid ha en strategisk interesse $i$ at folkeretten respekteres. Men folkerettens regler for militær maktbruk i utlandet bør tas i betraktning også av andre grunner. Folkeretten gir notoritet, og gjør at militær maktbruk i utenlandsoperasjoner fremstår hjemme og ute som en aktivitet som er i tråd med Norges interesser, påregnelig, forutsigbar og sågar prinsipiell. Folkeretten gir rettssikkerhet, og giør at vi utstyrer våre soldater med et minimum av rettssikkerhetsgarantier for oppdrag $\mathrm{i}$ land langt borte. Endelig gir folkerettsdekning også større utsikter til at operasjoner kan gjennomføres effektivt. Oppdrag av ulik militær 
karakter kan sjelden utføres optimalt når norske soldater befinner seg i en prekær rettslig situasjon.

Rett er ikke alltid ensbetydende med riktig. Folkeretten gir imidlertid notoritet, rettssikkerhet og effektivitet, noe som bør være grunnleggende forutsetninger når norske myndigheter velger å sende norske soldater ut for å delta i militære operasjoner på fremmed jord, hvor terrenget ofte er ulendt og farvannet grumsete.

\section{Litteratur}

Afghanistan (2003) Utenriksministeren, Brev adressert til FNs Generalsekretær, 12.11.2015. Tilgjengelig på http://www.securitycouncilreport.org/atf/cf/\%7B65BFCF9B-6D27-4E9C-8CD3-CF6E4FF96FF9\%7D/ AfghS2003986.pdf

Al-Arabiya (2015) Russia, Iran, Syria 'cooperating' on Baghdad security, Bagdad, 21.11.2015. Tilgjengelig på http://english.alarabiya.net/en/News/middle-east/2015/09/27/-Russia-Iran-Syria-cooperating-on-Baghdadsecurity-issues-.html

Amnesty International (2014) Absolute Impunity - Militia Rule in Iraq, rapport, 12.11.2015. Tilgjengelig på https://www.amnesty.org.uk/sites/default/files/absolute_impunity_iraq_report.pdf

Arimatsu, Louise \& Michael Schmitt (2014) «Attacking 'Islamic State' and the Khorasan Group: Surveying the International Law Landscape», Colombia fournal of Transnational Law Bulletin 53(1): 1-29.

Audiencia Nacional (2010) «Ashraf-saken», Central Investigation, Court Number 4, Madrid, Spania 27.12.10

Authorization for Use of Military Force (2001) AUMF, Public Law No. 107-40, \2(a), USA.

Australia (2015) Permanent representant til FN, Brev adressert til Presidenten av Sikkerhetsrådet, 15.01.2016. Tilgjengelig på http://www.securitycouncilreport.org/atf/cf/\%7B65BFCF9B-6D27-4E9C8CD3-CF6E4FF96FF9\%7D/ s_2015_693.pdf

Bartolini, Giulio (2012) «Air Targeting in Operation Unified Protector in Libya: Jus ad Bellum and IHL Issues: an External Perspective», Recueil de la Société internationale de droit militaire et de droit de la guerre XIX: 242-279.

Bjørgo, Petter (2014) «Fra FN til NATO, Norske styrker som eksportvare?», Militcere Studier, Forsvarets stabskole 6: 1-97.

Blanchard, Christopher \& Carla Humud (2015) The Islamic State and U.S. Policy. Congressional Research Service Report, 14.01.2016. Tilgjengelig på http://fas.org/sgp/crs/mideast/R43612.pdf

Bonn-avtalen (2001) Agreement on Provisional Arrangements in Afghanistan Pending the Re-establishment of Permanent Government Institutions, 21.11.2015. Tilgjengelig på http://www.un.org/News/dh/latest/ afghan/afghan-agree.htm

Brahimi, Lakhdar (2001) Security Council Briefing. Vedlegg til Bonn-avtalen, 21.11.2015. Tilgjengelig på http:// www.un.org/news/dh/latest/afghan/brahimi-sc-briefing.htm

Canada (2015) Permanent representant til FN, Brev adressert til Sikkerhetsrådets President, 21.11.2015. Tilgjengelig på https://documents-dds-ny.un.org/doc/UNDOC/GEN/N15/092/85/PDF/N1509285.pdf? OpenElement

Chan, Gabrielle (2014) Australian Military Role Unclear as Iraq Minister Rejects Idea of Foreign Troops, Guardian, 06.01.2016. Tilgjengelig på http://www.theguardian.com/australia-news/2014/oct/15/australianmilitary- role-unclear-as-iraq-minister-rejects-idea-of-foreign-troops

CBS (2014) Iraq's prime minister says no to foreign troops, 06.01.2016. Tilgjengelig på http://www.cbsnews. com/news/iraq-prime-minister-haider-al-abadi-says-no-to-foreign-troops/

Chilcot rapporten (2016) The Report of the Iraq Inquiry, Report of a Committee of Privy Councellors, 08.08.2016. Tilgjengelig på http://www.iraqinquiry.org.uk/the-report/

Cordesman, Anthony \& Sam Khazai (2014) Iraq in Crisis, Center for International and Strategic Studies report, Rowman \& Littlefield, mai.

David, Eric (2008) Principes de droit des conflits armés. Bruxelles: Brulyant.

Deeks, Ashley (2013) "Consent to the Use of and Force and International Law Supremacy», Harvard International Law fournal 54: 1-60.

Det Hvite Hus (2014) Pressemelding, Den amerikanske presidentens uttalelser om flyangrep i Syria, 21.11.2015. Tilgjengelig på http://www.whitehouse.gov/the-press-office/2014/09/23/statement

Det Hvite Hus (2014a) Pressetalsmannens kontor, Den amerikanske presidentens uttalelser om ISIL, 21.11.2015. Tilgjengelig på https://www.whitehouse.gov/the-press-office/2014/09/10/statement-presidentisil-1 
Dinstein Yoram (2011) War, Aggression and Self-Defence, $5^{\text {th }}$ ed. Cambridge: Cambridge University Press.

Doswald-Beck, Louise (1985) «The Legal Validity of Military Intervention by Invitation of the Government», British Yearbook of International Law 56 1: 189-252.

Eriksen, Ine-Marie (2014) Forsvarsministerens redegjørelse om norske bidrag til Irak og Afghanistan, Stortinget, 05.11.14.

FN-pakten (1945) 26.06. Tilgjengelig på https://treaties.un.org/doc/publication/ctc/uncharter.pdf

FN (2006) Sikkerhetsrådsmøte Debate on Escalating Crisis Between Israel, Lebanon, møte 5489, 15.11.2015. Tilgjengelig på http://www.un.org/press/en/2006/sc8776.doc.htm

FN (2014) Sikkerhetsråds President (2014) Uttalelse 21.11.2015. http://www.un.org/en/ga/search/view_doc. asp?symbol=S/PRST/2014/20

FN (2014a) Hjelpemisjon for Irak UNAMI, Report on the Protection of Civilians in the Armed Conflict in Iraq: 6 fuly-10 September 2014. Human Rights Office of the United Nations High Commissioner for Human Rights \& United Nations Assistance Mission for Iraq, 06.01.2016. Tilgjengelig på http://www.ohchr.org/ Documents/Countries/IQ/UNAMI_OHCHR_POC_Report_FINAL_6J uly_10September2014.pdf

FN (2015) Høykommisær for menneskerettigheter, Report on the human rights situation in Iraq in the light of abuses committed by the so-called Islamic State in Iraq and the Levant and associated groups, 06.01.2016. Tilgjenglig på http://www.securitycouncilreport.org/atf/cf/\%7B65BFCF9B-6D27-4E9C-8CD3-CF6E4FF96FF9\%7D/a_ hrc_28_18.pdf

FN (2015a) Høykommisær for menneskerettigheter, Report of the UN High Commissioner for Human Rights, Technical Assistance and Capacity Building, lagt frem for Generalforsamlingen, 15.11.2015. Tilgjengelig på http://www.securitycouncilreport.org/atf/cf/\%7B65BFCF9B-6D27-4E9C-8CD3-CF6E4FF96FF9\%7D/ a_hrc_30_66.pdf

FN (2015b) Generalsekretærs rapport, First report of the Secretary-General pursuant to paragraph 7 of resolution 2233 (2015), 15.11.2015. Tilgjengelig på http://www.securitycouncilreport.org/atf/cf/\% 7B65BFCF9B6D27-4E9C-8CD3-CF6E4FF96FF9\%7D/s_2015_819.pdf

FNs Sikkerhetsrådsresolusjoner; 1368 (2001) USA/Al-Qaeda;1373 (2001) USA/Al-Qaeda; 1386 (2001) Afghanistan; 1483 (2003) Irak; 1510 (2003) Afghanistan; 1511 (2003) Irak; 1546 (2004) Irak; 1973 (2011) Libya; 2061 (2012) Irak; 2170 (2014) ISIL og Jabhat al-Nusra; 2178 (2014) Fremmede terrorist krigere; 2199 (2015) Syria; 2216 (2015) Jemen; 2233 (2015) Irak; 2249 (2015) Syria og Irak.

Frankrike (2015) Fast representant til FN, Brev av adressert til FNs Sikkerhetsråd, 05.01.2016. http://www. securitycouncilreport.org/atf/cf/\%7B65BFCF9B-6D27-4E9C-8CD3-CF6E4FF96FF9\%7D/s_2015_745.pdf

Gardam, Judith (2004) Necessity, Proportionaliy and the Use of Force by States. Cambridge: Cambridge University Press.

Gill, Terry (2010) Military Intervention at the Invitation of a Government, i Gill, Terry \& Dieter Fleck (red.) The Handbook of International Law of Military Operations. New York: Oxford University Press (252-259).

Gray, Christine (2008) International Law and the Use of Force, Cambridge: Cambridge University Press.

Gray, Christine (2013) «The use of force for humanitarian purposes» i Elgar (red.) Research handbook on international conflict and security law: jus ad bellum, jus in bello and jus post bellum. Cheltenham: Northampton (229-255).

Heintschel von Heinegg, Wolff (2007) «Benevolent Third States in International Armed Conflicts: The Myth of the Irrelevance of the Law of Neutrality» i Schmitt, Michael \& Jelena Pejic (red.) International Law and Armed Conflict: Exploring the Faultines. Leiden: Martinus Nijhoff (543-568).

Human Rights Watch (2016) World Report, Kapittel om Irak: Abuses by pro-government forces, 05.06.2016. Tilgjengelig på https://www.hrw.org/world-report/2016/country-chapters/iraq\#b634c3

ICJ (1971) Den internasjonale domstolen i Haag Legal Consequences for States of the Continued Presenceof South Africa in Namibia. Rådgivende uttalelse, ICJ (1971:16) 21.06.71.

ICJ (1986) Den internasjonale domstolen i Haag Military and Paramilitary Activities in and Against Nicaragua. Dom, ICJ (1986:14) 27.06.86.

ICJ (1996) Den internasjonale domstolen i Haag Legality of the Threat or Use of Nuclear Weapon. Rådgivende uttalelse, ICJ (1996:226) 08.07.96.

ICJ (2003) Den internasjonale domstolen i Haag Case Concerning Oil Platforms. Dom, ICJ (2003:161) 06.11.03.

ICJ (2004) Den internasjonale domstolen i Haag Legal Consequences of the Construction of a Wall in the Occupied Palestinian Territory. Rådgivende uttalelse, ICJ (2004:136) 09.07.04.

ICJ (2005) Den internasjonale domstolen i Haag Armed Activities on the Territory of the Congo. Dom, ICJ (2005:168) 19.12.05. 


\section{Cecilie Hellestveit}

ICRC (2005) Sedvanerettsstudie. Henckaerts, Jean-Marie \& Louise Doswald-Beck (red.) ICRCs Study on Customary International Humanitarian Law. Genève: ICRC, Cambridge: Cambridge University Press.

ICRC (2009) Interpretive Guidance on the Notion of Direct Participation in Hostilities, Niels Melzer (red.) Geneva. Tilgjengelig på https://www.icrc.org/eng/assets/files/other/icrc-002-0990.pdf

ILC (2001) Den internasjonale folkerettskommisjonen, Draft articles on State Responsibility. Tilgjengelig på http://legal.un.org/ilc/texts/instruments/english/draft_articles/9_6_2001.pdf

Institute for the Study of War (2015) Syria Update, 06.01.2016. Tilgjengelig på http://www.understandingwar. org/syria-blog; Iraq Update. Tilgjengelig på http://www.understandingwar.org/iraq-blog

Irak (2014) Permanent representant til FN, Brev til FNs Sikkerhetsråds President, 06.01.2016. Tilgjengelig på http://www.securitycouncilreport.org/atf/cf/\%7B65BFCF9B-6D27-4E9C-8CD3-CF6E4FF96FF9\%7D/s_ 2014_691.pdf

Irak (2015) Brev fra Iraks utenriksdepartement, adressert til den Norske ambassaden i Amman, 06.01.2016.

Irak (2015a) Permanent representant til FN, Note verbale til FNs Generalsekretær, 07.01.2016. Tilgjengelig på http://www.securitycouncilreport.org/atf/cf/\%7B65BFCF9B-6D27-4E9C-8CD3-CF6E4FF96FF9\%7D/s_ 2015_723.pdf

Irak (2015b) Permanent representant til FN, Brev til Sikkerhetsrådets President, 06.01.2016. Tilgjengelig på http://www.securitycouncilreport.org/atf/cf/\%7B65BFCF9B-6D27-4E9C-8CD3-CF6E4FF96FF9\%7D/s_ 2015_963.pdf

Israel (2006) Permanent representant til FN, Brev adressert til FNs Sikkerhetsråd, 21.11.2015. Tilgjengelig på http:/www.securitycouncilreport.org/atf/cf/\%7B65BFCF9B-6D27-4E9C-8CD3-CF6E4FF96FF9\%7D/ LebanonS2006515.pdf

Jessup, Phillip (1968) A modern Law of Nations. Hamden Conn: Archon Books.

Kelsen, Hans (1950) The Law of the United Nations. New York: Praeger.

Military Technical Agreement (2002) Brev med avtale fra britisk FN ambassadør til FNs Sikkerhetsråd, 10.01.2016. Tilgjengelig på http://reliefweb.int/sites/reliefweb.int/files/resources/9B11C79DE13BB700C1256 B5300381E4F-unsc-afg-25jan.pdf

Norge (2015) Ambassade i Amman, Brev 5/2015 adressert til Iraks Utenriksdepartement, 18.01.15.

New York Times (2011) «Iraqis Were Unwilling To Accept Terms of SOFA» 21.11.11.

New York Times (2014) «Diplomatic Note Promises Immunity From Iraqi Law for U.S. Advisory Troops» 23.06.14.

Obama, Barak (2014a) War Powers Resolution Regarding Syria. Brev fra Presidenten til Speaker of the House of Representatives og President pro temore of the Senate, 08.11.2015. Tilgjengelig på https://www.whitehouse. gov/the-press-office/2014/09/23/letter-president-war-powers-resolution-regarding-syria

Obama, Barak (2014b) War Powers Resolution Regarding Iraq. Brev fra Presidenten til Speaker of the House of Representatives og President pro temore of the Senate, 21.11.2015. Tilgjengelig på https://www.whitehouse. gov/the-press-office/2014/09/23/letter-president-war-powers-resolution-regarding-iraq

Obama, Barak (2014c) Uttalelse om flyangrep i Syria. South Lawn, 21.11.2015. Tilgjengelig på https://www. whitehouse.gov/the-press-office/2014/09/23/statement-president-airstrikes-syria

Obama, Barack (2015) Brev fra Presidenten, Authorization for the Use of United States Armed Forces in Connection with the Islamic State of Iraq and the Levant, 08.11.2015. Tilgjengelig på http://www. whitehouse.gov/the-press-office/2015/02/11/letter-president-authorization-use-united-states-armed-forcesconnection

Pommier, Bruno (2011) «Le recours à la force pour protéger les civils et l'action humanitaire: le cas libyen et au-delà», Revue internationale de la Croix-Rouge 93(3): 171-193.

Qatar (2015) Permanent representant til FN, Brev adressert til Presidenten av Sikkerhetsrådet fra representantene fra Bahrain, Kuwait, Qatar, Saudi Arabia og de Forenede Arabiske Emirater, 06.01.2016. Tilgjengelig på http://www.securitycouncilreport.org/atf/cf/\%7B65BFCF9B-6D27-4E9C-8CD3-CF6E4FF96FF9\%7D/s_ 2015_217.pdf

Regjeringen (2011) Pressemelding 41/2011 Avslutter det militere bidraget $i$ Libya, 06.01.2016. Tilgjengelig på https:/www.regjeringen.no/no/aktuelt/avslutter-det-militare-bidraget-i-libya/id661685/

Roma Statuttene for den permanente internasjonale straffedomstolen (1998) 17.07. Tilgjengelig på https:// www.icc-cpi.int/nr/rdonlyres/ea9aeff7-5752-4f84-be94-0a655eb30e16/0/rome_statute_english.pdf

Ryan \& Jaffe (2015) «Obama weighs moving US troops closer to front lines in Syria, Iraq.» Washington Post 27.10 .15 .

Schmitt, Michael (2002) «Counter-terrorism and the Use of Force in International Law», Israeli Yearbook of Human Rights 32: 53-116. 
Simma, Bruno (red.) (2012) The Charter of the United Nations: A Commentary. Article 2(4), Vol. 1, 3. utgave. Randelzhofer, Albrect \& Oliver Dorr, Oxford Commentaries on International Law.

Smith, Ben \& Arabella Thorp (2010) The legal basis for the invasion of Afghanistan, House of Commons Library Standard Note SN/IA/5340, 07.11.2015. Tilgjengelig på http://www.parliament.uk/briefing-papers/ SN05340.pdf

Solberg, Erna (2014) Redegjørelse for Stortinget av statsministeren om norske bidrag til Irak og Afghanistan. 05.november, sak nr.2, 08.11.2015. Tilgjengelig på https://www.stortinget.no/stid/2014/si141105-02.html

Strøm Eriksen, Anne-Grete (2005) Redegjørelse for Stortinget av forsvarsministeren om fremtidig innretning av norske militcere styrkebidrag $i$ Afghanistan og Irak, 06.01.2016. Tilgjengelig på https://www.stortinget.no/no/ Saker-og-publikasjoner/Publikasjoner/Referater/Stortinget/2005-2006/051109/3/

Syria (2015) Permanent representant til FN, Brev adressert til FNs Sikkerhetsråds President og FNs General Sekretær, 11.11.15.

Trapp, Kimberley (2007) «Back to Basics: Necessity, Proportionality, and the Right of Self-Defense against Non-state Terrorist Actors», International Criminal Law Quarterly 56: 141-156.

Tyrkia (2015) Permanent representant til FN, Brev adressert til Sikkerhetsrådets President, 24.07.15. Tilgjenglig på http://www.securitycouncilreport.org/atf/cf/\%7B65BFCF9B-6D27-4E9C-8CD3-CF6E4FF96FF9\%7D/ s_2015_563.pdf

Tyskland (2015) Permanent representant til FN, Brev adressert til Sikkerhetsrådets President, 10.12.15. Tilgjengelig på http://www.securitycouncilreport.org/atf/cf/\%7B65BFCF9B-6D27-4E9C-8CD3-CF6E4FF96FF9\%7D/s_ 2015_946.pdf

USA (2001) Lov om autorisasjon av militærmakt, AUMF (2001) Public Law No. 107-40:115.

USA (2008) Permanent representant til FN, Uttalelse av Zalmay Khalilzad om situasjonen i Gaza, 31.12.08. Tilgjengelig på http://www.usun-ny.us/press_releases/20081231_381.html

USA (2011) Justisdepartementet, White paper, Lawfulness of a Lethal Operation Directed Against a US Citizen who is a senior Operational Leader of al-Qaeda or an Associated Force, 08.11.11. http://www.justice.gov/sites/ default/files/oip/legacy/2014/07/23/dept-white-paper.pdf

USA (2014) Forsvarsdepartementet Operation Inherent Resolve: Targeted Operations against ISIS Terrorists. Tilgjengelig på http://www.defense.gov/home/features/2014/0814_iraq/

USA (2014b) Forsvarsdepartementet, Pressebriefing med Kirby, John og Mayville, William, 23.09.14. Tilgjengelig på http://www.defense.gov/Transcripts/Transcript.aspx? TranscriptID $=5505$

USA (2014c) Permanent representant til FN, Brev av 23.09.14 adressert til FNs Generalsekretær, Tilgjengelig på http://www.securitycouncilreport.org/atf/cf/\%7B65BFCF9B-6D27-4E9C-8CD3CF6E4FF96FF9\%7D/s_ 2014_695.pdf

USA (2014e) Sentralkommandoen CENTCOM (2014) Pressemelding, Iraq and Syria Operations Against ISIL Designated as Operation Inherent Resolve 15.10.14. Tilgjengelig på http://www.centcom.mil/en/ news/articles/iraq-and-syria-ops-against-isil-designated-as- operation-inherent-resolve

USA (2015) Militæretterretningsbyrået DIA, Felles uttalelse House Armed Services Committee, US Defense Intelligence Agency, 03.02.15.

USA (2016) Lov om autorisasjon av nasjonalt forsvar, NDAA (2016), Public Law No. 114-92:1223.

USA-Irak (2008) Bilateral avtale, Strategic Framework Agreement for a Relationship of Friendship and Cooperation between the United States and the Republic of Iraq. 17.11.08. Tilgjengelig på http://www.state.gov/ documents/organization/122076.pdf

Vattel, Emerich de (1758) Droit des gens; ou, Principes de la loi naturelle appliqués à la conduite et aux affaires des nations et des souverains. Preliminaries, (Section XVIII).

Wien-konvensjonen om diplomatiske relasjoner (1961), 24.04.61. Tilgjengelig på http://legal.un.org/ilc/texts/ instruments/english/conventions/9_1_1961.pdf

Wien-konvensjonen om traktatrett (1969), 23.05.69. Tilgjengelig på https://reaties.un.org/doc/Publication/ UNTS/Volume1 155/volume-1155-I-18232-English.pdf

Youssef, Mohamed (2013) «Security Council resolution 1973: a new interpretation of the notion of protection of civilians?» i Panara, Carlo \& Gary Wilson (red.) The Arab spring: new patterns for democracy and international law. Leiden: M. Nijhoff (145-167). 